\title{
The significance of genetic erosion in the process of extinction. I. Genetic differentiation in Salvia pratensis and Scabiosa columbaria in relation to population size
}

\author{
R. VAN TREUREN, ${ }^{*}$ R. BIJLSMA,* W. VAN DELDEN* \& N. J. OUBORG $\dagger$ \\ *Department of Genetics, University of Groningen, Kerklaan 30, 9751 NN Haren, and †Department of Plant Ecology, \\ Institute for Ecological Research, P.O. Box 40,6666 ZG Heteren, The Netherlands
}

\begin{abstract}
As part of a programme to determine the importance of the loss of genetic variation for the probability of population extinction, the amount of allozyme variation was determined in 14 populations of Salvia pratensis and in 12 populations of Scabiosa columbaria. Significant correlations were found between population size and the proportion of polymorphic loci (Salvia: $r=0.619$; Scabiosa: $r=0.713$ ) and between population size and mean observed number of alleles per locus (Salvia: $r=0.540$; Scabiosa: $r=0.819$ ). Genetic differentiation was substantially larger among small populations than among large populations: in Salvia $G_{\mathrm{ST}}$ was 0.181 and 0.115 , respectively, and in Scabiosa 0.236 and 0.101 , respectively. The results are discussed in relation to genetic drift, inbreeding and restricted gene flow.
\end{abstract}

Keywords: conservation biology, extinction, genetic erosion, population size, Salvia pratensis, Scabiosa columbaria.

\section{Introduction}

Due to the activities of man, populations of many plant and animal species have become small, fragmented and isolated. Research is needed to develop effective measures for conservation. Until the beginning of the last decade conservation was mainly the domain of ecologists, but recently much attention has been focused on the importance of the population genetic aspects (Soulé \& Wilcox, 1980; Frankel \& Soulé, 1981; Schonewald-Cox et al., 1983; Soulé, 1986, 1987).

Population genetic theory predicts that, as a consequence of genetic drift and inbreeding, small populations will have decreased levels of genetic variation. Even favourable alleles may be lost and the potential to adapt to a changing environment may be seriously diminished (Vrijenhoek, 1985). Moreover, inbreeding results in increased levels of homozygosity which may cause inbreeding depression (Frankel R., 1983). Both processes may thus lead to 'genetic erosion', reduce the fitness of individuals in a population and increase the chance of the extinction of the population. Ultimately this may lead to the extinction of the species. The deleterious effects of genetic erosion in populations, however, can be counteracted by gene flow renewing the genetic variation.

Because experimental data about the significance of genetic erosion in extinction are virtually absent, we started a project to examine these processes in two plant species in The Netherlands: Salvia pratensis and Scabiosa columbaria. These species were selected because: (i) the number of populations has significantly declined in the last decades, (ii) they occur in both small and large populations, (iii) both are thought to be predominantly outbreeding. The research described in this paper is part of a comprehensive research project to determine the importance of genetic factors for population extinction and to develop effective management measures that could prevent species from becoming extinct. In this paper we present data on the amount of allozyme variation and the extent of genetic differentiation in relation to population size.

\section{Materials and methods}

Both Salvia pratensis and Scabiosa columbaria are gynodioecious, protandric perennials and are diploid with $2 n=18$ (Tutin et al., 1972) and $2 n=16$ (Tutin et 
al., 1976), respectively. Salvia occurs in dry, sunny, calcareous grassland on river dunes and dikes, Scabiosa in dry, grassy places on calcareous soils. The number of $(1 \times 1 \mathrm{~km})$ grid squares in which Salvia and Scabiosa was observed, declined between 1950 and 1980 from 92 to 78 and from 82 to 52 , respectively (Mennema et al., 1985). In 1988 only 39 populations of Salvia and 24 populations of Scabiosa were recorded (Ouborg et al., 1989).

The location of the populations examined is given in Fig. 1. The mean distance between the examined populations and their nearest neighbouring population was $4 \mathrm{~km}$ for Salvia and $7 \mathrm{~km}$ for Scabiosa. Because both species are pollinated mainly by bees, which are known to forage within considerably smaller distances (Levin \& Kerster, 1974), gene flow between populations by means of pollen was expected to be restricted. Because seeds of both species have no special means of transport, seed dispersal may even be less important (Levin \& Kerster, 1974).

In 1988 , the size of small populations was determined by counting the total number of flowering individuals, whereas the size of large populations was estimated by stratified sampling of square metres and the subsequent extrapolation to total population area. Populations were grouped in two distinct size classes (small and large populations). This classification, however, was partly arbitrary. Criteria were such that the difference in population size between the largest small population and the smallest large population had to be substantial and that the difference in number of populations in each size class had to be as small as possible (Table 1).

Individual plants were sampled in all populations in 1988 by cutting pieces of leaf material. In small populations as many plants as possible were sampled, whereas in large populations about 50 individuals were sampled with regular spacing, using the whole population area. The samples were put in plastic bags with a small amount of water and kept in a portable cooler. In the laboratory the samples were stored in a refrigerator $\left(4^{\circ} \mathrm{C}\right)$ until the moment of electrophoretic analysis. The activity of the enzymes remained sufficiently high for at least 3 weeks. Of the 29 enzyme systems tested for electrophoresis, 10 showed a sufficiently clear pattern and were used for genetic analyses (Table 2).

\section{Electrophoretic procedure}

Buffer systems. Tris-citrate $\mathrm{pH} 7.0, \mathrm{LiOH}$-borate $\mathrm{pH}$ 8.3 and tris-borate EDTA $\mathrm{pH}$ 8.6. Apart from GPI, ICD and PGD for Salvia, which were performed on polyacrylamide, electrophoretic analyses were carried out on starch gels. Electrophoretic methods and recipes for buffers (except tris-borate EDTA pH 8.6) and staining solutions (except SORDH) are described
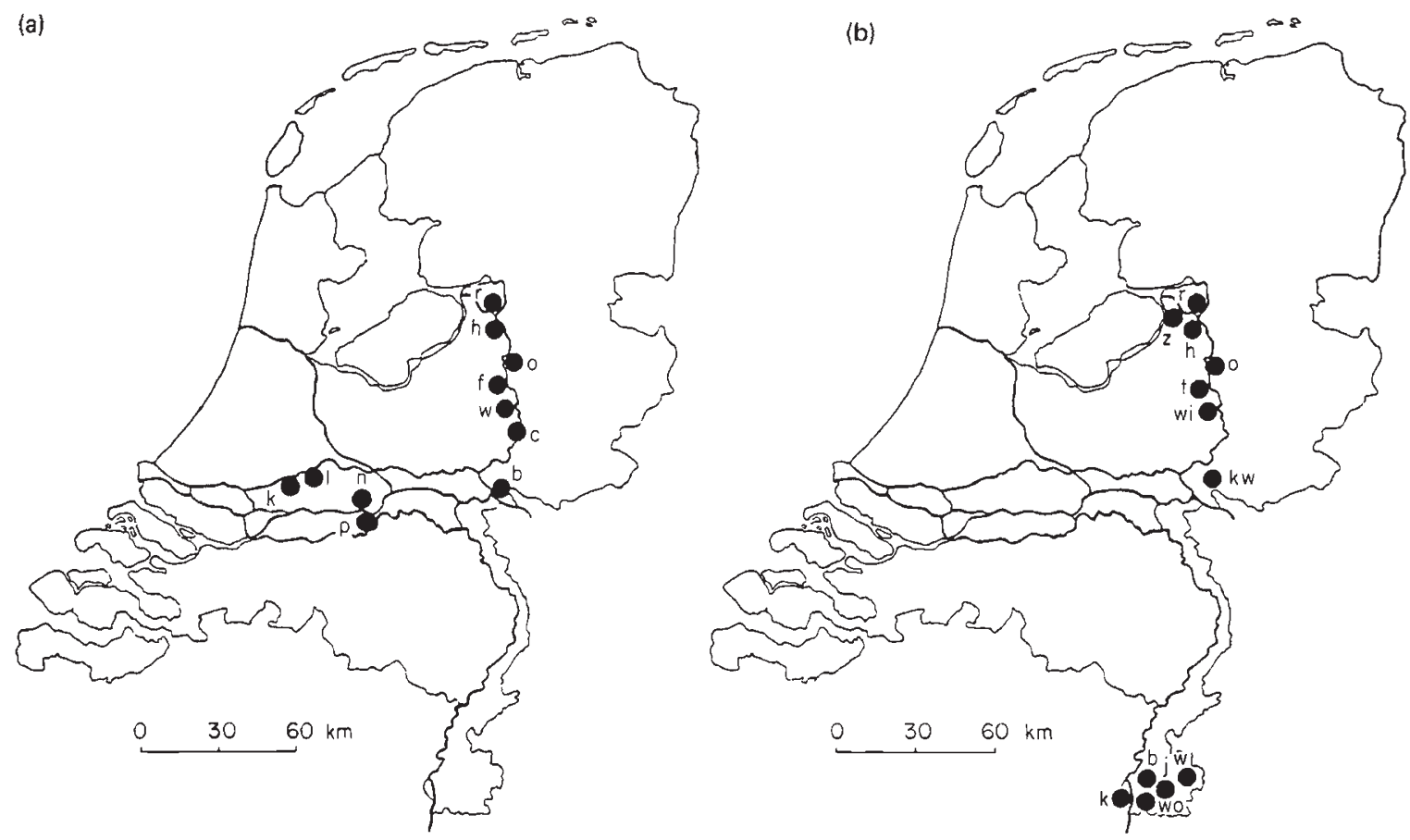

Fig. 1 Location of the examined populations of Salvia pratensis (a) and Scabiosa columbaria (b) in The Netherlands. For Salvia, the following three locations consisted of two (sub)populations (their interpopulational distances given between brackets $): \mathrm{f}(320 \mathrm{~m}), \mathrm{c}(580 \mathrm{~m})$ and $\mathrm{b}(160 \mathrm{~m})$. 
Table 1 Examined populations of Salvia and Scabiosa with their abbreviated name (A), number of flowering $(N)$ and sampled $(n)$ individuals. Populations are grouped according to size (see text)

\begin{tabular}{llrrllrr}
\hline Small populations & (A) & $N$ & $n$ & Large populations & (A) & $N$ & \\
\hline Salvia & & & & & & & \\
$\quad$ Forten 1 & $\mathrm{f} 1$ & 5 & 5 & Olst & $\mathrm{o}$ & 300 & 49 \\
Forten 2 & $\mathrm{f} 2$ & 14 & 14 & Ruitenberg & $\mathrm{r}$ & 300 & 50 \\
Neerijnen & $\mathrm{n}$ & 17 & 17 & Cortenoever 2 & $\mathrm{c} 2$ & 310 & 66 \\
Lexmond & 1 & 30 & 20 & Wilpse klei & $\mathrm{w}$ & 400 & 50 \\
Hoenwaard & $\mathrm{h}$ & 46 & 34 & Bijland 2 & $\mathrm{b} 2$ & 1000 & 36 \\
Bijland 1 & $\mathrm{b}$ & 60 & 14 & Koekoekswaard & $\mathrm{k}$ & 1500 & 60 \\
Cortenoever 1 & $\mathrm{c}$ & 60 & 10 & & & & \\
Piekenwaard & $\mathrm{p}$ & 61 & 43 & & & & \\
Scabiosa & & & & & & & \\
Hoenwaard & $\mathrm{h}$ & 14 & 6 & Terwolde & $\mathrm{t}$ & 200 & 50 \\
Kwartierse dijk & $\mathrm{kw}$ & 35 & 25 & Wilpse klei & wi & 200 & 50 \\
Ruitenberg & $\mathrm{r}$ & 90 & 42 & Bemelerberg & $\mathrm{b}$ & 300 & 50 \\
Kannerhei & $\mathrm{k}$ & 100 & 21 & Wolfskop & wo & 25000 & 48 \\
Zalk & $\mathrm{z}$ & 118 & 30 & Olst & $\mathrm{o}$ & 50000 & 50 \\
& & & & Julianagroeve & $\mathrm{j}$ & 75000 & 50 \\
& & & & Wrakelberg & w & 100000 & 50 \\
\hline
\end{tabular}

Table 2 Enzymes studied and buffer-systems used for Salvia and Scabiosa

\begin{tabular}{lllll}
\hline & & & Buffer $\mathrm{pH}$ \\
\cline { 4 - 5 } Enzyme & Abbreviation & E.C.number & Salvia & Scabiosa \\
\hline Sorbitol dehydrogenase & SORDH & 1.1 .1 .14 & 8.3 & - \\
Malic enzyme & ME & 1.1 .1 .40$. & 8.3 & - \\
Isocitrate dehydrogenase & ICD & 1.1 .1 .42$. & 7.0 & - \\
Phosphogluconate dehydrogenase & PGD & 1.1 .1 .44$. & 7.0 & 7.0 \\
Peroxidase & PEROX & 1.11 .1 .17 & 8.6 & - \\
Glutamate-oxaloacetate transaminase & GOT & 2.6 .1 .1$. & 8.3 & 8.3 \\
Phosphoglucomutase & PGM & 2.7 .5 .1$. & 8.6 & 8.6 \\
Aconitase & ACN & 4.2 .1 .3$. & - & 8.3 \\
Triose phosphate isomerase & TPI & 5.3 .1 .1$. & 8.6 & $7.0 / 8.6$ \\
Glucose phosphate isomerase & GPI & 5.3 .1 .9$. & & \\
\hline
\end{tabular}

in Hofman (1988). The recipe of the tris-borate EDTA buffer-system $\mathrm{pH} 8.6$ was: $12.11 \mathrm{~g}$ Tris/l aquadest $(0.1 \mathrm{M}), 1.86 \mathrm{~g}$ EDTA/l aquadest $(0.005 \mathrm{M})$, adjust to $\mathrm{pH} 8.6$ with boric acid. The staining solution of SORDH was: $50 \mathrm{ml} 0.06 \mathrm{M}$ Tris- $\mathrm{HCl} \mathrm{pH} 8.1(7.27 \mathrm{~g}$ Tris/l aquadest, adjust to $\mathrm{pH} 8.1$ with 25 per cent $\mathrm{HCl}$ ), $125 \mathrm{mg}$ sorbitol, $20 \mathrm{mg} \mathrm{NAD}{ }^{+}, 5 \mathrm{mg}$ MTT, $1 \mathrm{mg}$ PMS, $50 \mathrm{mg}$ pyrazol and $50 \mathrm{mg}$ sodium pyruvate. Because of the complexity of some enzyme-activity patterns, due to the presence of a gene duplication ( $R$. Van Treuren \& R. Bijlsma, in preparation), electrophoresis of Scabiosa for GPI was performed on two buffer systems. On tris-citrate $\mathrm{pH} 7.0$ electrophoretic mobility was higher (better separated bands), whereas trisborate EDTA pH 8.6 gave a higher resolution (sharper bands).

\section{Estimation of genetic variation}

To estimate the amount of genetic variation, the following measures were calculated: (i) the proportion of polymorphic loci $(P)$, (ii) the mean observed number of alleles per locus $\left(A_{0}\right)$ and (iii) gene diversity $\left(H_{\mathrm{e}}\right)$. A locus was considered polymorphic if the frequency of the most frequent allele was less than 0.99. Gene diversity and standard genetic distance were computed 
according to Nei (1987) in which corrections were made for small sample sizes.

\section{Results}

Enzyme variability is given in Table 3 . Because the allelic variation and number of subunits of Pgd-2 for Scabiosa was only recently established, the results for this locus were omitted from the genetic analyses. In order to determine if the inheritance of the allozymes was Mendelian, crosses were performed with plants grown from seeds collected in 1987. Because not all genotypes were represented in the seed samples, only the relatively frequent variants could be tested (Table 4). No significant deviation from Mendelian inheritance was found for any of the loci examined. Independent segregation was observed for most loci, strong linkage was only found between $P g d-1$ and $G p i-2$ of Scabiosa. Recombination between these loci was estimated to occur at a frequency of about 6 per cent (R. Van Treuren \& R. Bijlsma, in preparation).

To establish the relationship between population size and the amount of genetic variation, corrections for differences in sample size were calculated in two different ways. Firstly, Spearman's rank correlation

Table 3 Enzyme variability of Salvia and Scabiosa. Loci coding for similar enzymes were numbered in ascendence according to the electrophoretic mobility of their gene products. Alleles were named according to their relative position to the $\mathrm{N}$ (normal) allele, which was present in every population and which was usually the most frequent. $\mathrm{I}_{1}$ was intermediate between $\mathrm{S}$ (slow) and $\mathrm{N}, \mathrm{I}_{2}$ between $\mathrm{N}$ and $\mathrm{F}$ (fast)

\begin{tabular}{|c|c|c|c|c|c|}
\hline \multicolumn{3}{|l|}{ Salvia } & \multicolumn{3}{|c|}{ Scabiosa } \\
\hline Locus & $\begin{array}{l}\text { Isozyme } \\
\text { structure }\end{array}$ & Alleles & Locus & $\begin{array}{l}\text { Isozyme } \\
\text { structure }\end{array}$ & Alleles \\
\hline Sordh & Monomeric & $\mathrm{S}, \mathrm{N}$ & Pgd-1 & Dimeric & $\mathrm{S}, \mathrm{N}, \mathrm{F}$ \\
\hline$M e-1$ & Dimeric & $\mathrm{S}, \mathrm{I}_{1}, \mathrm{~N}$ & Pgd-2 & Dimeric & $\mathrm{S}, \mathrm{N}$ \\
\hline$I c d-1$ & $?$ & $\mathrm{~N}$ & Pgd-3 & Monomeric & $\mathrm{S}, \mathrm{N}$ \\
\hline$P g d-1$ & Dimeric & $\mathrm{S}, \mathrm{N}, \mathrm{F}$ & Got-1 & Dimeric & $\mathrm{S}, \mathrm{N}$ \\
\hline$P g d-2$ & Dimeric & $\mathrm{S}, \mathrm{N}, \mathrm{F}$ & Pgm-1 & Monomeric & $\mathrm{S}, \mathrm{N}, \mathrm{F}$ \\
\hline Perox & Monomeric & $\mathrm{S}, \mathrm{I}_{1}, \mathrm{~N}, \mathrm{~F}$ & Pgm-2 & $?$ & $\mathrm{~N}$ \\
\hline Got-1 & Dimeric & $\mathrm{S}, \mathrm{I}_{1}, \mathrm{~N}, \mathrm{~F}$ & Acn-1 & Monomeric & $\mathrm{S}, \mathrm{N}, \mathrm{F}$ \\
\hline Got-2 & Dimeric & $\mathrm{S}, \mathrm{N}, \mathrm{F}$ & Acn-2 & Monomeric & $\mathrm{S}, \mathrm{N}$ \\
\hline Pgm-1 & Monomeric & $\mathrm{S}, \mathrm{N}, \mathrm{F}$ & $T p i-1$ & Dimeric & $\mathrm{S}, \mathrm{N}, \mathrm{F}$ \\
\hline Pgm-2 & Monomeric & $\mathrm{S}, \mathrm{I}_{1}, \mathrm{~N}, \mathrm{I}_{2}, \mathrm{~F}$ & Tpi-2 & Dimeric & $\mathrm{N}, \mathrm{F}$ \\
\hline Tpi-1 & Dimeric & $\mathrm{S}, \mathrm{I}_{1}, \mathrm{~N}$ & Gpi-1 & Dimeric & $\mathrm{S}, \mathrm{N}, \mathrm{F}$ \\
\hline Tpi-2 & Dimeric & $\mathrm{N}, \mathrm{F}$ & Gpi-2 & Dimeric & $\mathrm{S}, \mathrm{I}_{1}, \mathrm{~N}, \mathrm{I}_{2}, \mathrm{~F}$ \\
\hline Gpi-1 & $?$ & $\mathrm{~N}$ & Gpi-3 & $?$ & $\mathrm{~N}$ \\
\hline
\end{tabular}

Table 4 Parental genotypes $(P)$ and genotype numbers in the $F_{1}$-generation with Chi-square values for the deviation from Mendelian segregation

\begin{tabular}{|c|c|c|c|c|c|c|c|c|c|c|c|c|}
\hline \multicolumn{8}{|l|}{ Salvia } & \multicolumn{5}{|c|}{ Scabiosa } \\
\hline Locus & $P g d-2$ & Perox & Got-1 & Got-2 & Pgm-1 & Pgm-2 & Tpi-1 & $P g d-1$ & Got-1 & $T p i-1$ & Gpi-1 & Gpi-2 \\
\hline \multirow[t]{2}{*}{$\mathbf{P}$} & NF & NF & SN & SN & NF & NN & $\mathrm{I}_{1} \mathrm{~N}$ & SN & SN & SN & SN & NF \\
\hline & SN & NF & SN & $\mathrm{SN}$ & NF & $\mathrm{NI}_{2}$ & NN & SN & SN & $\mathrm{SN}$ & SN & NF \\
\hline \multirow[t]{4}{*}{$\mathrm{F}_{1}$} & SN 7 & NN 10 & SS 6 & SS 5 & NN 9 & NN 22 & $\mathrm{I}_{1} \mathrm{~N} 19$ & SS 22 & SS 23 & SS 16 & SS 8 & NN 17 \\
\hline & SF 14 & NF 11 & SN 20 & SN 15 & NF 13 & $\mathrm{NI}_{2} 15$ & NN 18 & SN 61 & SN 58 & SN 41 & SN 16 & NF 40 \\
\hline & NN 9 & FF 8 & NN 16 & NN 9 & FF 7 & & & NN 24 & NN 26 & NN 12 & NN 10 & FF 15 \\
\hline & NF 7 & & & & & & & & & & & \\
\hline$\chi^{2}$ & 3.541 & 1.966 & 4.857 & 1.138 & 0.586 & 1.324 & 0.027 & 2.178 & 0.925 & 2.913 & 0.353 & 1.000 \\
\hline
\end{tabular}


coefficients were calculated between population size, sample size and the amount of genetic variation. Subsequently, by keeping sample size constant, the partial correlation coefficients (Sokal \& Rohlf, 1981) between population size and the amount of genetic variation were computed. Significant correlations were found between population size and the proportion of polymorphic loci (Salvia: $r=0.807, t=4.534, P<0.0005$; Scabiosa: $r=0.622, t=2.386,0.01<P<0.025)$ and between population size and the mean observed number of alleles (Salvia: $r=0.570, \quad t=2.303$, $0.01<P<0.025 ; \quad$ Scabiosa: $\quad r=0.653, \quad t=2.584$, $0.01<P<0.025)$, although it should be stressed that $P$ and $A_{0}$ are not independent measures. However, no significant correlation was found between population size and gene diversity (Salvia: $r=0.051, t=0.169$, $0.4<P$; Scabiosa: $r=0.135, t=0.410,0.3<P<0.4$ ). Secondly, repeated samples of equal size were taken from the master file (Salvia: sample size $=5$; Scabiosa:
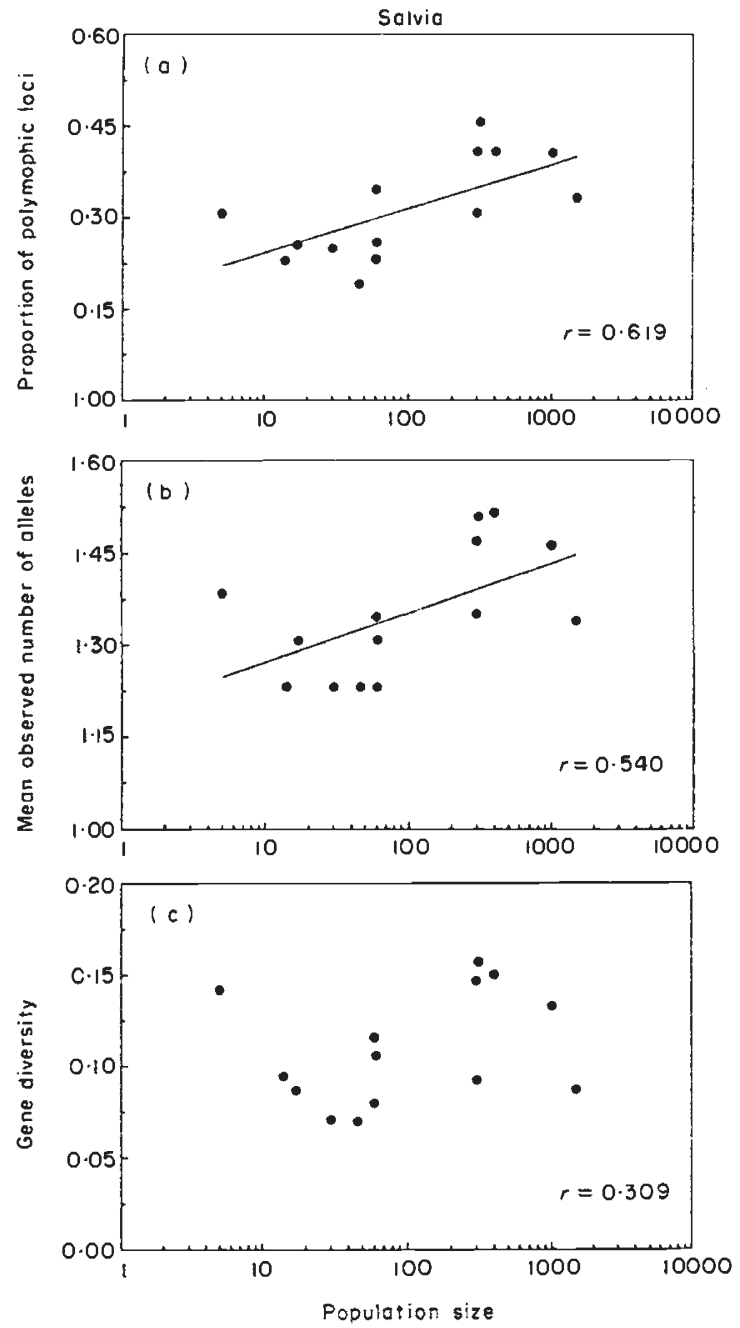

sample size $=6$ ), the number of repetitions in each population were determined by the original sample size. Subsequently, the mean values of $P, A_{0}$ and $H_{\mathrm{e}}$ were used in a weighted regression (Fig. 2). Again, significant positive correlations were found between the population size and proportion of polymorphic loci (Salvia: $r=0.619, t=2.73,0.005<P<0.01$; Scabiosa: $r=0.713, t=3.21,0.001<P<0.005)$ and between population size and the mean observed number of alleles (Salvia: $r=0.540, t=2.22,0.01<P<0.025$; Scabiosa: $r=0.819, t=4.51,0.0005<P<0.001$ ), but not between the population size and gene diversity (Salvia: $r=0.309, t=1.12,0.1<P<0.15$; Scabiosa: $r=0.490, t=1.78,0.05<P<0.075)$. The lack of correlation between the population size and $H_{\mathrm{e}}$ in both species was mainly due to the smallest population showing a relatively high value and the largest population showing a relatively low value.

To establish the extent of genetic differentiation
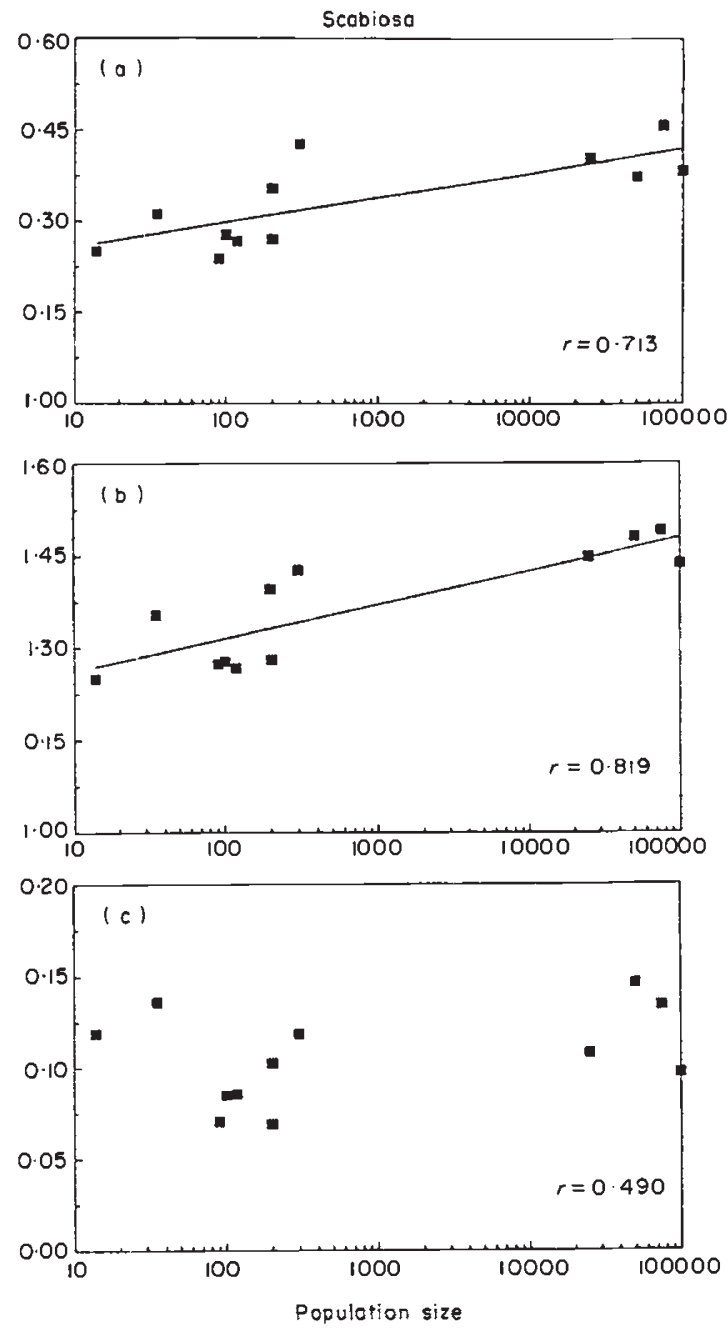

Fig. 2 Weighted regression of proportion of polymorphic loci (a), mean observed number of alleles (b) and gene diversity (c) on population size (log scale) for both Salvia and Scabiosa. $r$ is the correlation coefficient. 
Table 5 Analysis of gene diversity (Nei, 1987) in populations of Salvia and Scabiosa, together with the Chi-square value of $G_{\text {ST }}$ for the deviation from zero. The coefficient of gene differentiation $\left(G_{\mathrm{ST}}\right)$ is the proportion of the total gene diversity $\left(H_{\mathrm{T}}\right)$ that can be attributed to the average gene diversity between populations $\left(H_{\mathrm{T}}-H_{\mathrm{S}}\right)$. Deviation of $G_{\mathrm{ST}}$ from 0 (no differentiation) was tested by using the Chi-square test of heterogeneity of gene frequencies (Workman \& Niswander, 1970)

\begin{tabular}{|c|c|c|c|c|c|c|c|c|c|c|}
\hline & \multicolumn{5}{|l|}{ Salvia } & \multicolumn{5}{|c|}{ Scabiosa } \\
\hline & Locus & $H_{\mathrm{T}}$ & $H_{\mathrm{S}}$ & $G_{\mathrm{ST}}$ & $\chi^{2}$ & Locus & $H_{\mathrm{T}}$ & $H_{\mathrm{S}}$ & $G_{\mathrm{ST}}$ & $\chi^{2}$ \\
\hline \multirow[t]{13}{*}{ All populations } & Sordh & 0.034 & 0.030 & 0.122 & $58.6^{* *}$ & Pgd-1 & 0.237 & 0.206 & 0.131 & $190.9^{* *}$ \\
\hline & $M e-1$ & 0.077 & 0.061 & 0.203 & $202.9^{* *}$ & Pgd-3 & 0.022 & 0.021 & 0.055 & $34.8^{* *}$ \\
\hline & Icd-1 & 0.000 & 0.000 & - & - & Got-1 & 0.271 & 0.213 & 0.212 & $170.4^{* *}$ \\
\hline & Pgd-1 & 0.094 & 0.072 & 0.237 & $75.5^{* *}$ & Pgm-1 & 0.228 & 0.178 & 0.220 & $252.0^{* *}$ \\
\hline & $P g d-2$ & 0.214 & 0.197 & 0.081 & $131.1^{* *}$ & $P g m-2$ & 0.000 & 0.000 & - & - \\
\hline & Perox & 0.562 & 0.436 & 0.224 & $434.9^{* *}$ & Acn-1 & 0.008 & 0.007 & 0.035 & $38.4^{*}$ \\
\hline & Got-1 & 0.198 & 0.167 & 0.155 & $294.4^{* *}$ & Acn-2 & 0.095 & 0.083 & 0.122 & $92.5^{* *}$ \\
\hline & Got-2 & 0.128 & 0.118 & 0.080 & $100.6^{* *}$ & $T p i-1$ & 0.257 & 0.231 & 0.103 & $122.8^{* *}$ \\
\hline & Pgm-1 & 0.115 & 0.101 & 0.120 & $94.4^{* *}$ & $T p i-2$ & 0.044 & 0.041 & 0.078 & $54.9^{* *}$ \\
\hline & $P g m-2$ & 0.190 & 0.165 & 0.130 & $209.2^{* *}$ & Gpi-1 & 0.130 & 0.102 & 0.216 & $260.6^{* *}$ \\
\hline & Tpi-1 & 0.140 & 0.129 & 0.073 & $124.0^{* *}$ & Gpi-2 & 0.262 & 0.199 & 0.238 & $417.5^{* *}$ \\
\hline & $T p i-2$ & 0.015 & 0.014 & 0.076 & $41.1^{* *}$ & Gpi-3 & 0.000 & 0.000 & - & - \\
\hline & Gpi-1 & 0.000 & 0.000 & - & - & - & - & - & - & - \\
\hline \multicolumn{11}{|c|}{ Populations (all loci) } \\
\hline All & & 0.136 & 0.115 & 0.156 & & & 0.129 & 0.107 & 0.175 & \\
\hline Small & & 0.128 & 0.105 & 0.181 & & & 0.131 & 0.100 & 0.236 & \\
\hline Large & & 0.144 & 0.127 & 0.115 & & & 0.124 & 0.112 & 0.101 & \\
\hline
\end{tabular}

$* 0.01<P<0.025$.

**P $P<0.0005$.

among populations, an analysis of gene diversity was performed (Table 5). Significant differentiation was found for all loci of both species. For all loci combined, $G_{\mathrm{ST}}$ was 0.156 and 0.175 for Salvia and Scabiosa, respectively. A subsequent analysis of gene diversity in the group of small populations and in the group of large populations showed that the coefficient of gene differentiation was substantially higher in the group of small populations (Salvia: $G_{\mathrm{ST}}=0.181$ and 0.115 , respectively; Scabiosa: $G_{\mathrm{ST}}=0.236$ and 0.101 , respectively).

\section{Discussion}

The basic assumption underlying our research project was the hypothesis that, as a consequence of genetic drift, inbreeding and restricted gene flow, small and isolated populations show decreased levels of genetic variation. The smaller number of variable loci and the smaller number of alleles found in the small populations are in agreement with this prediction. Similar results have been reported by Hamrick et al. (1979), Levin et al. (1979), Schmidtke \& Engel (1980), Moran \& Hopper (1983) and Karron (1987). No significant correlation was found between population size and gene diversity. However, 'rare' alleles reach high frequencies (possibly due to genetic drift) only in small populations. This effect will inflate $H_{\mathrm{e}}$ in small populations and consequently weaken the correlations between $H_{\mathrm{e}}$ and the population size. Therefore, gene diversity appears not to be a useful comparative measure of genetic variation in small populations. Moreover, many other population characteristics, such as population structure (neighbourhood size, relative plant density, etc.), effective population size and breeding system might affect not only $H_{\mathrm{e}}$ but also the other measures of genetic variation. Varvio-Aho (1981) for example showed that gene diversity in the Finnish waterstrider was not correlated with population size but clearly with effective population size. The impact of these other population characteristics is currently being investigated.

If genetic drift predominantly affects allelic frequencies in populations, and levels of gene flow between populations are low, population genetic theory predicts genetic differentiation between populations. The results of the analysis of gene diversity agree with this prediction. Loveless \& Hamrick (1984) analysed the available data that describes genetic differentiation from a large number of studies and 
computed the mean $G_{\mathrm{ST}}$ values for a number of variables. They found that $G_{\mathrm{ST}}$ was $0.118,0.109$ and 0.077 for predominantly outcrossing species $(n=76)$, dioecious species $(n=3)$ and long-lived perennials $(n=48)$, respectively. The mean $G_{\mathrm{ST}}$ of 43 predominantly outcrossing, long-lived perennials was 0.068 . Compared to these values, Salvia $\left(G_{\mathrm{ST}}=0.156\right)$ and Scabiosa $\left(G_{\mathrm{ST}}=0.175\right)$ show substantial genetic differentiation, probably resulting from a significant amount of genetic drift in the small populations. This explanation is supported by the finding that small populations are more differentiated from each other than are large populations. Together with the observation that average gene diversity did not differ substantially between the group of small and large populations (Table 5), our results are similar to those of Brakefield (1989). Rich et al. (1979) also found a significant increase in the variance of allelic frequencies among populations due to genetic drift and showed that this increase was inversely proportional to population size. This agrees with our observation that the rare alleles are found in high frequency only in small populations, resulting in larger variances of allelic frequencies and subsequently larger $G_{\mathrm{ST}}$ values in the group of small populations.

If allelic frequencies in populations are predominantly affected by genetic drift and gene flow between populations is restricted, it is also to be expected that genetic differentiation occurs even within relatively short distances. No significant correlations are found between geographic and genetic distances (Salvia: $r=-0.022, t=-0.206, P<0.4 ;$ Scabiosa: $r=0.167$, $t=1.357,0.075<P<0.1$ ), which suggests that gene flow is indeed restricted. The genetic structure of both species resembles an island model of population structure, as found for Desmodium nudiflorum (Schaal \& Smith, 1980) and Sarracenia purpurea (Schwaegerle \& Schaal, 1979), where populations are geographically isolated from each other with the chance of gene flow between populations being greatly reduced.

Estimates of the average level of gene flow between natural populations can be derived from the $G_{\mathrm{ST}}$ values (Slatkin \& Barton, 1989). $G_{\mathrm{ST}}$ values of 0.156 (Salvia) and 0.175 (Scabiosa) are equivalent to $N_{\mathrm{m}}=1.166$ and $N_{\mathrm{m}}=0.990$ respectively, which means about only one migrant every generation. It has been suggested that the exchange of a single individual per generation among small endangered (sub)populations is sufficient to have them behave almost as one panmictic population (e.g. Franklin, 1980; Frankel \& Soulé, 1981; Allendorf, 1983; and Frankel, O. H., 1983). This general guideline for the management of small populations has been deduced from the equilibrium theory of Wright's infinite island model (Wright, 1931). However, popula- tions are generally not in equilibrium and the number of subpopulations is often small. Therefore, Varvio et al. (1986) studied the dynamics of genetic differentiation by using the finite island model and showed that the values of $H_{\mathrm{S}}, H_{\mathrm{T}}$ and $G_{\mathrm{ST}}$ in transient populations depend on the pattern of population subdivision and that it may take time for them to approximate the equilibrium values. Furthermore, the problem is complicated, among others, by fluctuating population sizes, subdivision and extinction of subpopulations. They therefore concluded that a single guideline, e.g. the 'one migrant per generation' rule, is not theoretically well justified.

In practice it is difficult to separate the role of selective and non-selective forces in genetic differentiation (Varvio-Aho, 1983). A way to examine the problem is to investigate whether the gene frequency variation is homogeneous over loci. If so, genetic differentiation is most likely to be the result of random processes because they affect all loci simultaneously and to the same extent (Lewontin \& Krakauer, 1973; Schaal, 1975; Varvio-Aho, 1983). $F_{\mathrm{ST}}$ values for individual alleles range from 0.031 to 0.243 (Salvia) and from 0.018 to 0.450 (Scabiosa). The ratio observed/ expected variance in $F_{\mathrm{ST}}$ which is Chi-square/d.f. distributed (Lewontin \& Krakauer, 1973) is 2.264 $(0.0005<P<0.001)$ and $3.332(P<0.0005)$ for Salvia and Scabiosa respectively, indicating that the differentiation of gene frequencies is clearly non-random. It seems unlikely, therefore, that the genetic constitution of both species can be entirely accounted for by random processes.

The amount of allozyme variation is clearly correlated with population size, the small populations being less variable. The genetic structure of Salvia and Scabiosa in The Netherlands can most satisfactorily be explained by an island model of population structure, with restricted gene flow between populations. This may imply that: (i) small populations are also less variable with respect to favourable alleles and/or fixed for deleterious ones, as a result of genetic drift and inbreeding, and/or (ii) small populations have reduced evolutionary potential but are well adapted to their current environment, as a result of selective forces. Experiments are planned to reveal whether: (i) plants in small populations show decreased fitness due to inbreeding depression, and/or (ii) plants in small populations experience different environmental conditions to which they have become adapted. The outcome of these experiments will be used to evaluate the effectiveness of measures proposed to restore the level of genetic variation. Hybridization of populations, for example, will increase genetic variability and fitness when populations are suffering from inbreeding 
depression but will result in outbreeding depression (Templeton, 1986) when populations have been adapted to differential local conditions.

\section{Acknowledgements}

We would like to thank an anonymous reviewer for constructive comments on the manuscript and A. C. Boerema, J. Haeck and K. Reinink for support in carrying out the experiments. This research project is partly subsidized by the Ministry of Agriculture, Nature Management and Fisheries.

\section{References}

ALLENDORF, F. W. 1983. Isolation, gene flow, and genetic differentiation among populations. In: Schonewald-Cox, C. S., Chambers, S. M., MacBryde, B. and Thomas, L. (eds), Genetics and Conservation: a Reference for Managing Wild Animal and Plant Populations, BenjaminCummings, London, pp. 51-65.

BRAKEFIELD, P. M. 1989. The variance in genetic diversity among subpopulations is more sensitive to founder effects and bottlenecks than is the mean: a case study. In: Fontdevila, A. (ed.), Evolutionary Biology of Transient Unstable Populations, Springer-Verlag, Berlin, pp. 145-161.

FRANKEL, O. H. 1983. The place of management in conservation. In: Schonewald-Cox, C. S., Chambers, S. M., MacBryde, B. and Thomas, L. (eds), Genetics and Conservation: a Reference for Managing Wild Animal and Plant Populations, Benjamin-Cummings, London, pp. 1-14.

FRANKEL, O. H. AND SOULE, M. E. 1981. Conservation and Evolution, Cambridge University Press, Cambridge.

FRANKEL, R. 1983. Heterosis. Reappraisal of Theory and Practice, Springer-Verlag, Berlin.

FRANKLIN, I. R. 1980. Evolutionary change in small populations. In: Soulé, M. E. and Wilcox, B. A. (eds), Conservation Biology: an Evolutionary-Ecological Perspective, Sinauer, Sunderland, pp. 135-149.

HAMRICK, J. L., LINHART, Y. B. AND MITTON, J. B. 1979. Relationships between life-history characteristics and electrophoretically detectable genetic variation in plants. Ann. Rev. Ecol. Syst., 10, 173-200.

HOFMAN, A. 1988. Starch gel electrophoresis: a tool for studying the phylogenetic systematics and population genetics of mosses. In: Glime, J. M. (ed.), Methods in bryology. Proc. Bryol. Meth. Workshop, Mainz, Hattori Bot. Lab., Nichinan, pp. 353-358.

KARRON, J. D. 1987. A comparison of levels of genetic polymorphism and self-compatibility in geographically restricted and widespread plant congeners. Evol. Ecol., 1, 47-58.

LEVIN, D. A. AND KERSTER, H. W. 1974. Gene flow in seed plants. Evol. Biol., 7, 139-220.

LEVIN, D. A., RITTER, K. AND ElLSTRAND, N. C. 1979. Protein polymorphism in the narrow endemic Oenothera organensis. Evolution, 33, 534-542.
LEWONTIN, R. C. AND KRAKauer, J. 1973. Distribution of gene frequency as a test of the theory of the selective neutrality of polymorphisms. Genetics, 74, 175-195.

LOVELESS, M. D. AND HAMRICK, J. L. 1984. Ecological determinants of genetic structure in plant populations. Ann. Rev. Ecol. Syst., 15, 65-95.

MENNEMA, J., QUENÉ-BoterenBrood, A. J. AND PLATE, C. L. 1985. Atlas van de Nederlandse flora. Zeldzame en vrij zeldzame planten. Bohn, Scheltema en Holkema, Utrecht.

MORAN, G. F. AND HOPPER, S. D. 1983. Genetic diversity and the insular population structure of the rare granite rock species, Eucalyptus caesia benth. Aust. J. Bot., 31, 161-172.

NEl, M. 1987. Molecular Evolutionary Genetics, Columbia University Press, New York.

OUBORG, N. J., VAN TREUREN, R., HAECK, J. AND REININK, K. 1989. Jaarverslag 1988. Institute for Ecological Research, Heteren.

RiCH, S. S., BELl, A. E. AND Wilson, S. P. 1979. Genetic drift in small populations of Tribolium. Evolution, 33, 579-584.

SCHAAL, B. A. 1975. Population structure and local differentiation in Liatris cylindracea. Am. Nat., 109, 511-528.

SCHAAL, B. A. AND SMITH, w. G. 1980 . The apportionment of genetic variation within and among populations of Desmodium nudiflorum. Evolution, 34, 214-221.

SCHMIDTKE, J. AND ENGEL, w. 1980. Gene diversity in tunicate populations. Biochem. Genet., 18, 503-508.

SCHONEWALD-COX, C. S., CHAMBERS, S. M., MACBRYDE, B. AND THOMAS, L. 1983. Genetics and Conservation: a Reference for Managing Wild Animal and Plant Populations, Benjamin-Cummings, London.

SCHWAEGERLE, K. E. AND SCHAAL, B. A. 1979. Genetic variability and founder effect in the pitcher plant Sarracenia purpurea L. Evolution, 33, 1210-1218.

SLATKIN, M. AND BARTON, N. H. 1989. A comparison of three indirect methods for estimating average levels of gene flow. Evolution, 43, 1349-1368.

SOKAL, R. R. AND ROHLF, F. J. 1981. Biometry (2nd edn), W. H. Freeman and Company, San Francisco.

SOULE, M. E. 1986. Conservation Biology: The Science of Scarcity and Diversity, Sinauer, Sunderland.

soulé, м. E. 1987. Viable Populations for Conservation, Cambridge University Press, Cambridge.

SOULÉ, M. E. AND wilcoX, B. A. 1980. Conservation Biology: an Evolutionary-Ecological Perspective, Sinauer, Sunderland.

TEMPLETON, A. R. 1986. Coadaptation and outbreeding depression. In: Soulé, M. E. (ed.), Conservation Biology: The Science of Scarcity and Diversity, Sinauer, Sunderland, pp. 105-116.

TUTIN, T. G., HEYwood, v. H., BURGES, N. A. et al. 1972. Flora Europaea (Part 3), Cambridge University Press, Cambridge.

TUTIN, T. G., HEYwood, v. H., BURGES, N. A. et al. 1976. Flora Europaea (Part 4), Cambridge University Press, Cambridge.

WRIGHT, s. 1931. Evolution in Mendelian populations. Genetics, 16, 97-159.

VARVIO, S. L., CHAKRABORTY, R. AND NEI, M. 1986. Genetic variation in subdivided populations and conservation genetics. Heredity, 57, 189-198. 
VARVIO-AHO, S. L. 1981. The effects of ecological differences on the amount of enzyme gene variation in Finnish waterstrider (Gerris) species. Hereditas, 94, 35-39.

VARVIO-AHO, S. L. 1983. Genetic variation in relation to dispersal efficiency. In: Oxford, G. S. and Rollinson, D. (eds), Protein Polymorphism: Adaptive and Taxonomic Significance, Academic Press, London, pp. 325-339.

VRIJENHOEK, R. C. 1985. Animal population genetics and disturbance: the effects of local extinctions and recolonizations on heterozygosity and fitness. In: Pickett, S. T. A. and White, P. S. (eds), The Ecology of Natural Disturbance and Patch Dynamics, Academic Press, London, pp. 265-285.

WORKMAN, P. L. AND NISWANDER, J. D. 1970. Population studies on Southwestern Indian tribes. II. Local genetic differentiation in the Papago. Am. J. Hum. Genet., 22, 24-49. 